\title{
Breaking the ice
}

\section{Fiamma Straneo and colleagues travelled to the heart of a glacial fjord in East Greenland to determine the causes of glacial retreat.}

Why did you choose this particular location for the fieldwork?

During a visit to the University of Maine in spring 2007, I met Gordon Hamilton — a glaciologist studying Helheim Glacier, which drains into Sermilik Fjord in Greenland. He described how, since 2003, the glacier had retreated and released large amounts of ice into the ocean. We discussed how one could measure the amount of freshwater released by the glacier into the fjord, and the potential impact of freshwater inputs on the circulation of the North Atlantic Ocean. A year later I was in Sermilik Fjord, with Hamilton and some colleagues, on a small boat surrounded by large icebergs.

What was the objective of the work? From studying the impact of Greenland's accelerating glaciers on the ocean, we became interested in the impact of the ocean on Greenland's glaciers. We wanted to see whether subtropical waters were reaching Greenland's glaciers, and triggering melting. We knew that increasing amounts of warm water were making their way up from the subtropics to Greenland. And scientists have suggested that the movement of Greenland's glaciers has accelerated as a result of increased melting at their termini. Yet direct evidence for the influence of subtropical waters on glacial dynamics has been lacking.

\section{What sort of data were you after?}

To establish whether the waters in Sermilik Fjord were driving melting at the edge of Helheim Glacier, and to determine where the waters were coming from, we needed to measure temperature, salinity and the speed at which the waters were moving throughout as much of the fjord as possible.

Temperature is key to understanding the water's capacity to melt the glaciers; temperature and salinity combined can be used to diagnose where the waters are coming from; and water velocity provides

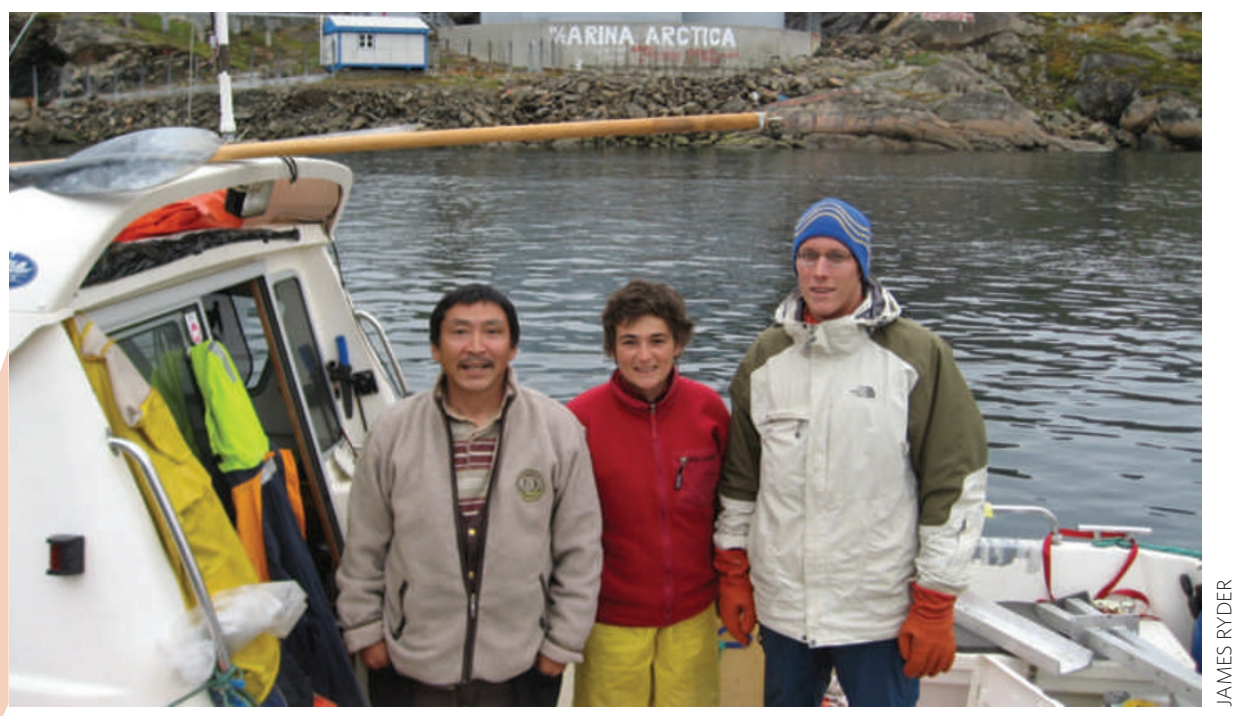

Testing the waters. Captain Arqaluk Jørgensen, Fiamma Straneo and David Sutherland after making measurements in an icy East Greenland fjord.

clues about how rapidly the waters circulate within the fjord.

\section{Did you encounter any difficulties?}

Normally we use large research vessels - fully equipped to make ocean measurements - to study ocean dynamics. However, such vessels are not suited to fjords clogged with large drifting icebergs, and we had to make do with a small boat that we could manoeuvre around the ice. Unfortunately, we did not know what the boat would look like until the morning we boarded. We therefore constructed an adjustable aluminium frame from which we could lower instruments to depths of $1,000 \mathrm{~m}$. Despite our efforts, the frame still needed to be adjusted, and we had to file it down to fit it on board. Staying put in the fjord also proved to be tricky - the surface currents were so fast that we often had to attach ourselves to a nearby iceberg with a grappling hook to remain in position.

\section{Any low points?}

Battling our way through a sea of ice one long rainy day when we were trying to get to the head of the fjord. We spent hours and hours trying to find a route through the ice, got very cold and wet, and eventually had to turn back because it was getting dark.
What was the highlight of the expedition?

The captain of the local vessel was a native East Greenlander, Arqaluk, whose ancestors have lived in and around Sermilik Fjord for many generations. His in-depth knowledge of the fjord, its waters, the ice and the weather made our mission possible. It was amazing to witness how well adapted he was to his environment: he could see icebergs in the fog and hear boats approaching long before any of us could, and he could steer the boat around blocks of ice for hours on end and never tire, get cold or grumpy. It reminded me of how invaluable local knowledge is and how important it is to preserve it.

\section{Did the trip give you any ideas for} future research projects?

Yes, absolutely. We still know very little about Greenland's glacial fjords and the ocean-glacier interactions therein. From our study it emerged that these fjords have highly energetic and variable circulations, and that we need more continuous observations if we are to understand how they work.

This is the Backstory to the work by

Fiamma Straneo and colleagues, published on page 182 of this issue. 